Article

\title{
Religious Education in (Post-)Pandemic Times; Becoming a Resilient Professional in a Teacher Academy
}

\author{
Monique van Dijk-Groeneboer(D) \\ Tilburg School of Catholic Theology, Tilburg University, 5037 AB Tilburg, The Netherlands; \\ m.c.h.vandijk@tilburguniversity.edu
}

Received: 30 September 2020; Accepted: 11 November 2020; Published: 17 November 2020

\begin{abstract}
The world seems a different place than it was before and now, more than ever, young people are faced with questions that cannot be avoided any longer: who am I? How and where can I find roots to endure the storms in my life? In what direction should I steer my compass? These questions are about resilience; the ability of individuals to cope with rapid societal change, both in their personal lives and in their professional career. Religious Education (RE) can help pupils and students to develop resilience by articulating these questions and pursuing them. The RE teacher's job is to simply be there with them, having considered these questions her- or himself. All teachers and educators have to start with their own reflection: who am I as an RE-teacher in this new, uncertain and rapidly transforming world? Research on how to start this reflective formation process in RE is essential to attracting the attention that RE deserves. In this article, examples of pilots and the research conducted on them in the author's Teacher Academy are presented. The main goal is to contribute to the formation of young people to make them resilient and fit for the -as yet unknownfuture. They have to create this future and use their talents to effect the transformation that our world highly needs.
\end{abstract}

Keywords: religious education; moral compass; resilience; values

\section{Introduction}

The central research question in this article is: how can young people today become resilient? How can religious education contribute to the (re) discovery of the core values that can help young people become strong young adults who are ready for a professional career in uncertain and challenging times.

Today's world is such that pupils and students can no longer look to their teachers to provide solutions for the future. This is why they must be challenged to design their future themselves. The core values that guide moral decisions are the central starting point here. These values can be found above all in religion and philosophy, although young people are rarely aware of this. Religious education, especially, should be about forming the moral compass, so that young people learn to make their ethical choices based on these core values. This should be the central topic within RE today.

The article discusses two examples of how education that is provided at the author's Teacher Academy is working to form resilient people by bringing students and their teachers together in their development. The educational strategies as well as research conducted with these strategies is presented. These two different examples show precisely that there is a range of new educational practices to work together with pupils and students on this process of professional identity development.

The role of teachers is crucial in this regard, because teachers must, on the one hand, set an example of how a moral compass can be developed in all openness, whereas on the other they cannot predetermine the exact form this will eventually take. 


\section{2. (Post-)Pandemic World: Pausing to Reflect}

A few months ago, nobody could have imagined the world we are living in now, in which we have to socially distance and stop traveling to work, college or across the world. My hope was that I would be able to write "post-pandemic" without parentheses, but unfortunately the end of the crisis is not yet in sight. For decades, the sky seemed the limit, or better, we took to the skies and flew wherever we wanted to go. Although debate was already underway on global issues such as climate change, the search for sustainability and the negative effects of the enormous growth in technology and digitization, no one can now ignore these issues any longer. In our world, which is on hold due to the Covid-19 virus, we have become aware of the vulnerability of our lives and of our world. We are forced to stop and realize that we must be more careful with our earth and the way we treat everything that lives on it. This is in fact a common theme in the Christian tradition, but one which seems to have disappeared in the more secularized West. However, as the virus has spread across the world and has become "our common enemy", this idea has now also regained currency in this part of the world. This is an opportunity to consider the connection we have with each other. We must become aware that we are a community of people (we are all God's creation, as Christians say), gathered from across the world and interconnected with each other.

We have taken a long time to realize this. The economy and knowledge were the main motives for our actions, often without any consideration of whether the road taken was the best way to grow and expand. We were not in the habit to pause and reflect on the choices we made, to take care of our neighbors, to realize what we are doing to the planet through our consumption and the uneven distribution of resources among peoples. Even the high numbers of refugees moving across the world did not open our eyes. It turns out that we needed a virus to stop us in our tracks and realize these things.

\section{Young People's Challenges in Today's World}

For young people, in particular, this is proving to be a difficult time. Growing up and going out into the world happens by socializing with others and confronting one's own ideas and opinions with others (Pratt 2006; van Dijk-Groeneboer 2017). These discussions, as well as the establishing of boundaries, help young people to realize what choices they need to make to become the person they truly want to be. However, now that meeting their peers is possible only in online settings, communication is poor and less natural than they would want. Moreover, meeting up is essential to experiencing the safe environment required to share their vulnerability, to open up about their deepest sorrows, dreams, ideals and fears (Roebben 2011). This is essential to growing up and it is not possible in these days when gathering together is prohibited and is even subject to fines.

Despite young people's familiarity with mobile devices, usually only the good times are shared on Instagram and other social media; when they feel insecure or weary, what they need is a friend to meet in person, a real shoulder to cry on or an arm around them. Having to cope with this loneliness is a problem that has become very apparent in these months. Evidence for this is found in the higher incidence of depression and loneliness among students (Centre for Education Statistics and Evaluation 2015). In addition, the high figures of burnout among young people must be mentioned caused by high expectations on them and the endless possibilities that they have (Jongburnout 2020). Having too many choices and not pausing to consider which one fits your talents best, is an important reason for these psychological problems. Young people have to learn to be flexible if they are to weather the storms in today's world; to bend with the various expectations and new situations that present themselves, while at the same time staying rooted, grounded, so as not to be blown over (Delle Fave 2014). They have to be trained to become resilient, as will be elaborated on in the next paragraph. 


\section{Becoming Resilient}

Strongly resilient persons are better able to cope with the issues mentioned above (Brewer et al. 2019). The European Commission (2016) defines resilience as "the ability of an individual, a household, a community, a country or a region to withstand, cope, adapt, and quickly recover from stresses and shocks". This article emphasizes the importance of making young people strong and resilient. The focus is on developing a new perspective and new actions in which society, the economy, and governance play an important role. However, being resilient starts with the individual who will be making decisions that affect our world. This article offers two examples of approaches that can support pupils and students in shaping their position in a society that is characterized by growth. The meritocracy that our societies aspire to is in fact vitiated by dividing lines of ethnicity and levels of training, causing social distances between groups to emerge. In the projects presented here, strategies are put into practice to make young people aware of their individual resilience as well as of their public engagement that not only strengthens their resilience but also addresses the other stated challenges of ethnic divisions.

This should, therefore, be an important focus when educating young people. How can young people become strong individuals? How can they be resilient in this time when everything is insecure? Consider the everyday issues in their lives: the degree program they want to take is taught online instead of at school or on campus. The vacation they planned is cancelled and tickets are reimbursed in the form of vouchers. They are fired from their side-job due to too little work. The courses they follow are exclusively online, so they stay in their own room instead of spending time with old friends and making new ones. The job they hope to get after their degree does not exist anymore because of changes in the wider society. They want to move out of their parental home but there are no affordable rooms. It is not simple to deal with all this, and in addition they have to grow up and become an adult, which is a tough process as it is.

More than ever, young people have to rely on their own talents. They have to find solutions that were never found before, they have to be creative and the world needs them for that. It is an important task that faces them, and they have to be strong to deal with it. According to religious educator Schröder (Schröder 2017) strong rootedness and changing perspectives is needed to be able to weather these storms (van Dijk-Groeneboer 2017). Being aware of their own talents and finding nourishment for their roots helps them to become strong resilient adults. If they are able to combine this resilience with knowledge and creativity, they can become strong resilient professionals (Barbara-i-Molinero et al. 2017).

Of course, resilience in itself will not stop any virus from spreading. What resilience can do is to make young people stronger, to develop the ability to stand up when they need to and to create solutions for future problems which their educators cannot foresee. Especially in our individualistic society, religion can be helpful to build this resilience. Religion helps people to cope with situations and to propose new solutions to issues in the world (Zondag and van Uden 2017). Even if religion today is seen as a personal and private affair, it can still help individuals to find their deeper roots and core values. An important dynamic of religious education is to encourage personal reflection and to challenge the student to reassess their essential values. When this happens, a sense of community re-emerges, despite the fact that people's initial motives to turn to these routes may have been individualistic (Bernts and Berghuijs 2016). In today's world, people of different cultural backgrounds interact intensively due to globalization and to the large numbers of refugees, each with their own original values originated in their own historical and cultural background. This being the case, it is interesting to study how and where values originate and develop, and whether they are subject to external influences as described. The challenges in today's globalized world requires people to be resilient and to live with integrity because how we make sense of the world and the values and ways of making meaning are challenged by external influences and the value systems of others (Seymour et al. 1993). Once our knowledge has thus been enhanced, educators and societal organizations could benefit from this by developing value learning strategies that are able to mediate in situations of cultural conflict. Moreover, it will help foster a truly general dialogue about values, including in a wider setting, for instance in the political 
sense. This is crucial since previous generations have not been able to find effective solutions for the transformation that humanity needs to survive on this earth; the limits are already coming into view. The young generation has to come up with new creative solutions itself, becoming resilient in the societal changes and building on its own talents and inner set of core values. Young people's values are, therefore, the particular focus of this article. Religious education has to concentrate on facilitating them in becoming aware of these values and in developing new ideas that are aligned with this set of values, this moral compass.

\section{Young People's Values}

Religious Education is a subject that is contested, especially in non-religious schools, but also in religious schools with a highly secularized population. Despite this debate, even authors who oppose the compulsory status of RE in schools, like Hargreaves and White, acknowledge that the main purpose of RE is to further the moral development of pupils and to inculcate positive social values in the young (Hargreaves 1994; White 2004). Because of the nature of the subject, which uses strategies such as debating, "thinking through", reflecting and critical thinking, RE is the one subject in the school curriculum in which values are best discussed and sharpened. The fact that most values are embedded in traditions that are often rooted in religions is a further argument: the conveying of knowledge about religions and the practice of thinking through religion in RE mean that it is the perfect place to make young people aware of values and to help them form and adjust the moral compass that consists of these values.

To become resilient, young people must develop greater awareness of their talents and of the set of values upon which they base the decisions they make in their lives. Young people are faced with a plurality of values, due especially to individualization, detraditionalization and mediatization (Lindner 2017). Moreover, knowledge about values is a necessary precondition for being able to focus on teaching resilience by working with pupils' talents or by discussing values with each other in the classroom. However, the study of values that is required to gain this knowledge is beset by a number of problems.

However, the study of values to gain this knowledge is beset by a number of problems. An attempt to describe what values are shows that they are close to norms and desires. As Joas and Wiegandt (2008) have pointed out: "Values are different from norms because norms are restrictive, and values are attractive. [ ... ] Values do not limit the scope of our actions, but rather expand it." (p. 4). Furthermore, "While desires merely consist of what is desired, values express our notions of what is for us desirable. [ ... ] Our values cause us to appraise our desires." (p. 4) How can values defined in this way be understood? "We have to inquire what moves us to consider something as desirable, that is, what makes a certain idea of the good subjectively evident and emotionally captivating." (Joas and Wiegandt 2008, p. 5).

Young people and their values have been studied, for example from a theological perspective (Collins-Mayo et al. 2010), especially in Christian youth work (Jessen 2016), and in the educational field especially in relation to the subjects of "worldview" (Bakker and Montessori 2016) and "citizenship" (De Groot 2013). The largest values study ever carried out is the European Values Study (European Values Study 2020), which is based mainly on quantitative data. The EVS divides values into survival values (emphasis on economic and physical security) versus self-expression values (subjective well-being and quality of life on the one hand, and traditional values (religious beliefs and absolute moral standards) versus secular-rational values (freedom for individual choices and high tolerance of the opinions and beliefs of others) on the other. The EVS has nothing to say about how values are, or can be, influenced by education.

For twenty years, I have been conducting surveys every five years in the Netherlands to determine what values young people have (van Dijk-Groeneboer and Maas 2001, 2005; van Dijk-Groeneboer et al. 2008; van Dijk-Groeneboer and Brijan 2013; van Dijk-Groeneboer and Van Herpen-de Regt 2019). Similar results are also emerging from our research in Slovakia, Poland and the Czech Republic These 
results show how different the values amongst young people are in the various countries in Europe, and point us to how to develop these values, combine and mediate them and how to shape the thought patterns and actions based on them in these different contexts.

Despite the rise of individualization in Western Europe, values are not invented individually. In honing their personal values, young people are influenced mainly by their parents and, from the age of about 12 onward, by their peers. Values can, therefore, be studied and learning trajectories can be developed and implemented especially in family guidance, youth ministry and other youth work and educational settings, the settings in which these young people spend most of their time. Further research on the topic will be a great help for educators.

There is much to gain from conducting research to obtain a good idea of what kind of young people actually fill the classrooms, lecture halls or youth groups and what they value in life. Based on these data, educational strategies can be developed, ministry programs can be updated, and parents can be helped to raise their children to become good and happy human beings. Still, there is already much work to do on these moral compasses, to help young people to find their own set of values and to rely on their talents to work with them. It is time to teach resilience based on these values.

\section{RE: Teaching Resilience}

It is difficult to teach resilience cognitively, like when teaching a language or mathematics. To acquire resilience, it is necessary to experience reciprocal learning in which subject and object are more intertwined, and which includes practicing and thinking as well as experiencing and reflecting (Lanser-van der Velde 2007). For instance, in Dewey's school of thought (Dewey [1931] 1998), the goal of learning can be defined as helping ourselves and others to escape from precarious situations, such as we are currently experiencing in our pandemic world, and to find and create an environment in which we can flourish. Dewey preferred not to speak of development, as this suggests a certain predetermined outcome; instead, he used the word growth. Although he himself had no interest in teaching about and "into" religion, he did advocate openness in the learning process. This open-endedness is a particularly important requirement when teaching resilience by forming a moral compass.

In our Catholic Teacher Academy, we educate RE teachers in a two-year master's program. Furthermore, we collaborate with the other Teacher Academies at our University as well as with Teacher Academies in other parts of the Netherlands who all educate teachers in subjects other than religion (note: we are the only Catholic RE Teacher Academy in the country). As religious educators, we have to focus on our pupils and students, to become student centric. We have to allow them to navigate successfully through the world, a dangerous world in our eyes. In our classrooms, they have to build and reshape their moral compass which they use to make ethical decisions. They will have to make our society more sustainable, to improve it and to come up with creative action to devise new solutions for problems that are as yet unforeseen, just as the virus was unforeseen until very recently.

Thus, we have to train our pupils and students to use their knowledge to achieve and secure social values, use scientific procedures to facilitate human relationships and direct technological developments toward positive social effects. We want them to try to ensure that the world resembles our ideal world (the "kingdom of God", Christians would say) as much as possible. We want them to contribute to a world in which the values that we consider worth aspiring to are made palpable through application of their knowledge of our rich traditions and to use their social skills. In addition to helping them acquire this knowledge and training them in transferable skills, we must focus specifically on the choices that have to be made on this basis. Professional decisions are based on professional beliefs and interrelated with a personal value orientation, a moral compass.

We want young people to make decisions based on values such as solidarity with the less fortunate, empathy for and openness toward people with dissenting views and responsible management of our vulnerable world that is now clearly adrift. This type of social community thinking is currently often relegated to the background, even by religious pupils and students. A sense of community must again be fostered, to create a more caring world that is open to people of other cultural and 
religious backgrounds, people with different convictions and world views. Empathy with other people and awareness of the vulnerability of our earth are necessary if students are to develop this ethical decision making.

Martha Nussbaum's ideas (Nussbaum 2010) can help us here, because she underlines the importance of creativity and human imagination in education. She states that pupils and students must also be trained to regard people with different views, habits and customs as equals and not as "strangers". This is essential in today's world, and it is an important pillar in Religious Education. Therefore, I think that openness toward the other and a focus on one's own core values and ethical decision making should and can be features especially of RE classes. This ensures that students will not only learn to serve their own self-interest or wish to impress others; it will help them to live according to an inner morality and to strive to serve a higher purpose above and beyond their own self-interest (Brooks 2015).

The values one has forms their moral compass, which students use to orient their actions towards their goals. Furthermore, a person develops that compass by encounter (Selçuk 2018), by really listening to the stories of others. Other people's stories help people to view their own story. Looking through someone else's eyes can give a clear view on their own perspective, on the glasses through which they see lives, their profession and the context they work and live in. Pre-eminently Religious Education can help pupils to practice listening to others and help them become morally responsible and fully human (Shea 2018). And really listening means listening without immediately giving an answer, one's own opinion or judgment. Furthermore, an RE-teacher or religious educator has to listen and be open to what young people are really saying. It is important to not have one's own ideas ready, attempting to teach the pupils or students to think differently, but to stay with them in their process, and delve more deeply into what it is they are trying to say. A teacher really has to rely on their ability to find and further develop their own moral compass. This helps the young people become more resilient, to feel stronger and to become aware of their talents.

That is also why it helps to involve the great stories from the old religious traditions, because people have been making choices for as long as we know. People have always worked on developing their compass (Mitchell 2004). These stories do not have to be presented as the only right way to act, but they can provide new ideas for working with your moral compass. That is why these great stories must be told and why a lot can be learned from religious traditions but in the same open way in which you listen to pupils and students. "Listen" to these stories and make them valuable for your own life, the choices you are making. As a RE-teacher and religious educator, you can offer these stories without judging them, as either right or wrong, you should just let them be the stories they are. Everyone can then reflect on them freely and find the way towards shaping their core values in how they relate to these stories.

Resilience comes from listening to others as well as to one's own stories, to be able to change perspectives (Schröder 2017). However, of course, it also requires reflection, discussion and open dialogue in a safe space where it is possible to think about it out loud. That is the most important prerequisite for teaching resilience. First, the classroom has to be a safe space, then teacher and student can find the safe space in their own heart for it is there that the real strength lies. When the going gets tough, one has to be able to pause and find that safe space within oneself. Darling-Hammond points out that teachers are to be critical in crafting the learning environment for students (Darling-Hammond 2006). It is in a safe space that you will find the answers on how to deal with the chaos that exists outside, the first steps to act in this appealing outer world and the possibility to weigh the different options. If teachers are able to point their pupils or students in this direction, they can teach resilience.

Of course, knowledge too is needed to come up with new answers, to find new technological solutions, to develop new ideas to deal with climate change. Knowledge transfer is essential to become resilient. However, everyday there are moments in which people have to make decisions, however minor. Furthermore, in these moments, a person needs to know how to find one's set of values, 
one's moral compass, to make the right decision. This moral compass helps a person to take the blow, to consider one's options, and respond to it. It is in this way people become more resilient.

Obviously, the question as to how these practices of action, reflection and experience must be acquired, needs thorough attention, and the model of the hermeneutic space described by Sharkey (2019) can become helpful here. Sources are to be added at the different stages in the reflective process, and experience through encounter is of central importance as is attending to the meaning of the existential fact that we are in the world (pp. 134-35).

\section{Starting with Our Own Compass: Research in Building Resilient Professionals in RE}

Any program to develop one's own moral compass in order to be a more resilient person in this (post-)pandemic world, must start with teachers who are willing to facilitate this learning process. The trainers and educators have to be able to facilitate their pupils and students in becoming co-creators in order to find answers the teachers do not know themselves yet. It is not possible to teach these new solutions; all participants have to learn through them together. The pupils and students become change agents when they are really respected as true partners in the learning environment.

Anna Stetsenko (2017) has developed tools for an Agentive Transformative Approach (ATA) to teaching and learning in science education that corresponds closely to this. She describes how to create transformation studios in which teachers and students work together to transform their ideas and practices of teaching and learning. These studios are places where activists are trained to ensure ontologically and epistemologically crucial processes (p. 37). Each learner and each teacher then contribute to science authentically and through activism, thus participating in the human endeavor in the context of the world and of everyday realities. The participants add to existing knowledge through creative practices such as critiquing, questioning, probing and innovating. They observe how knowledge is grounded in the past collaborative processes of humanity and the normative and ethical implications that these contain. Furthermore, they explore how to ground knowledge in present and future community practices, in line with aspirations and hopes. Finally, they trace the historical roots of knowledge and transform this knowledge into action that is consistent with their aspirations and hopes. When a learning environment as described here is created and people become real change agents as activists, their development helps the world undergo transformative processes. Stetsenko also states, in line with my reasoning here: "The answers to these challenges [in today's world, MvD] have to be figured out by each individual learner qua actor of social communal practices and agent of the world- and history-in-the-making" (p. 44) This section is a sketch of an example from science classes where pupils become change agents. The following section will present two examples of this kind of teacher-trainer education that I work with in Religious Education classes. We can learn from these two examples and apply the practices in RE classes. Moreover, in RE we should focus transparently on the values that underlie the practice of critiquing, questioning, probing and innovating. This enhances the learning and reflective capabilities of the participants and adds to their resilience.

Firstly, at teachers' academies such as ours, an essential aspect for any trainee teacher is that they should do what they tell others to do: they should practice what they preach. To this end we have developed inspirational days that are held at the start of our Masters' program, in which teachers from our School and students who are training to become teachers, together form a professional learning community. This is done using our colleagues' expertise and our students' input. In this way, we jointly develop new teaching methods for secondary education. These new methods are used by internship students in real school classes, and then faculty members research their effectiveness. A first pilot study of these new, self-designed forms of work was carried out in 2016 (Kienstra et al. 2018). In this study the focus was on religious thinking through (Baumfield 2002) by using activating exercises and measuring the effectiveness of the teacher behaviour gearing active learning. Several new educational themes were introduced in our team of students and teachers and discussed in our own encounters and narrative dialogues. New educational assignments were then developed to introduce this method 
to the classroom at secondary schools, and they were tested in six lessons. The research consisted of student questionnaires, teacher logs and classroom teaching materials.

We adopted the conceptual framework of a religious education lesson in which the relationship between the teacher's behavior and the students' practice of "thinking through" religion played a central role. This relationship was influenced by the teacher's lesson design. Teaching scaffolds are important in guiding students through the learning process. The focus in this study was therefore on the role of the teacher. In a person-oriented teaching style, thinking through is an attempt to create an individual, reasonably justified worldview (van der Leeuw and Mostert 1991). 83 students participated in six lessons that were examined. A questionnaire was used in which students were able to score the teacher's activities include scaffolds used such as feedback, hints, instruction, explanation, modeling and questioning (Kienstra et al. 2018, p. 208). Correspondence analysis was used to analyze the data (p. 210).

New scaffolds were found that direct attention towards higher-thinking skills like listening, giving space and showing understanding. These scaffolds made the pupils realize the new way in which this lesson became thinking through education. In this study we focused on how students can be stimulated to think through religious stories and make a connection with their own values and truth, with their own moral compass. It became clear that higher-thinking skills were evident among students during the newly developed and implemented exercises and higher-order scaffolds were used by the teacher thus allowing students to work on their moral decision-making skills. This is how we develop evidence-based lessons (van Dijk-Groeneboer et al. 2017) which help pupils create their moral compass. The lessons make pupils aware of their inner set of values and gives them space to reflect on their judgments in exercises, and in life.

Secondly, another example is presented called the "learning workshops" in a secondary school teacher training program (Kools et al. forthcoming). Although the main focus is not on RE teachers and classes, the underlying line of reasoning as well as the explicit reflective actions add to build a moral compass and makes the example useful here. Learning workshops are learning environments in which students from different teacher training courses learn together with secondary education teachers. A learning workshop consists of teachers from different schools and students who are doing an internship at these schools. Four principles are used in the working method of the learning workshops: (1) focus on the student's learning; (2) work from your own learning need; (3) research and develop; (4) work and learn together. The learning workshops pursue three objectives: (a) training critical (future) teachers who have an eye for the students' learning; (b) integrating the training of students into the professionalization of experienced teachers; (c) contributing to school development. Exchange and reflection are essential in this form of inquiry-based learning (Lomos 2012): participants look for and study sources, test their own insights against those of others and compare the results of new working methods with predefined (learning) goals.

Usually, informal learning activities are stimulated by the principles of learning workshops. The interaction between participants in this professional learning community with different levels of experience is innovative: students and both beginning and experienced teachers all participate. In previous research, both experienced and junior teachers reported similar learning activities when they engaged in interactive learning, such as discussing; exchanging knowledge, experiences and information; giving and receiving advice and help; observing; reflecting; imitating and experimenting. This interaction appears to promote the learning of both the more and the less experienced participants (Geeraerts et al. 2018), and it stimulates regarding colleagues as an important resource for learning. This collaborative learning by teachers and students together in a learning community appears to be fruitful (Kools et al. forthcoming). As a result, the student is taught to become fully engaged in reflecting and learning because the teacher in the same group is similarly engaged in reflecting and learning.

Since 2016, we have developed and held several learning workshops every year (19 different workshops as of 2020). A learning workshop in our context consists of teachers from at least three 
different secondary schools and a maximum of six students who are doing an internship at these schools. The majority of the participating students come from university teacher training programs (educational masters). These students have already completed a university degree in an academic discipline (for example theology, history or science) and are now obtaining their first-degree qualification in an educational master's degree. For them, the learning workshop, in combination with their internship, is an intensive way to become acquainted with all aspects of teaching. In the research into learning in these workshops, the focus was mainly on the conditions in which this kind of learning can take place as effectively as possible. Here, too, learning is student centric. Paradoxically, focusing on the student is the greatest challenge for the teachers, because they have to accept that the learning objective or the possible learning outcome is not determined by them but by the student. Working in a joint professional learning community means that the participants have a safe space in which to reflect. Thus, all participants play an equal role in the learning process and higher-order learning is born. Researchers have established that the added value of the workshops lies in joint learning, having time to experiment in their own educational practice and reflecting critically on this together. The mix of participants from different subjects, schools and backgrounds (students as well as teachers) provides interesting results. Through the use of learning workshops, teacher training courses and schools can ensure together that training and professionalization are interwoven to create a broad continuous line of professional development towards the life-long learning attitude that is needed.

\section{Becoming a Resilient Professional: Conclusions and Discussion}

In this article, I have argued that RE-teachers and religious educators are the most important factor in this religious education program to train and form resilient professionals at our schools and academies. Pupils and students today can no longer look to their teachers to provide solutions for the future. RE teachers are no experts on moral compasses, nor are they particularly resilient or able to teach pupils and students by example. They are important because they themselves are seeking this resilience and they are themselves adrift in our uncharted post-pandemic world. The teachers themselves can learn the most in this entire process. Pupils and students must be challenged to design their future themselves.

Examples presented here such as cocreating in inspirational sessions, learning together in learning workshops and making agentive-transformative approaches in transformation studios can help teachers and educators to facilitate this co creation. The starting point is for RE-teachers and educators to be aware of their own core values and the normative and ethical consequences of their moral compass.

In order to turn students and pupils into co-creators, RE-teachers and educators have to open up and give the floor to their pupils and students if the latter are to become aware of their moral compass. The adult RE-teachers and educators are aware that the way we were used to living in our world is no longer possible, but they also know that they do not have the answers to make the difference by themselves. We need to fully facilitate the young people to be creative, to collaborate and to develop out-of-the-box ideas. This starts with the talents every individual has, and the values that are deeply true to a person. It starts with that moral compass. If we, as teachers and educators, develop our own compass consciously and openly, pupils and students can in turn do the same.

We can learn about our own compass and about the choices to be made by listening to the stories of others, in the here and now as well as in the past. We are now at a point in time where we can consciously do that. All the goals we have set in society have so far revolved around gaining knowledge and the greatest wealth. The Covid-19 virus has shown us that none of this works anymore in our world, if it ever did. We have come to realize that money and knowledge alone cannot help this world. We have to use this knowledge to distribute the resources in our world equally among all people, and to realize that we are living together on this planet and have to care for it and for each other. It is the only way to survive, and it is something that everyone knows deep in their heart.

Therefore, it is crucial in today's world that we create the space in our RE-classrooms to develop this moral compass, to find out what truly is the good life and to orient ourselves to this. We are 
aware that human beings are making moral choices, based on what they find in their heart, led by the spirit. This should be valued and taught at our schools and universities, so young people can stand up for it in the world and thus effect change. Furthermore, today's world is more than ready for this transformation. The young people who are growing up now are capable of knowing how to connect to that spirit, of making those choices, of sailing to this course and focusing on the light.

We need our pupils and students to acquire a moral compass to improve our world. Becoming aware of one's own core values and learning to make decisions based on this moral compass, can and needs to be practiced in RE classes. In these classes, they can learn to articulate their core values, their religious values, their world view, in a safe space. In the classroom, pupils and students develop their personal view on life, whether it is to be secular or religious, and they train their ethical decision-making using creativity and similar twenty-first-century skills, such as digital literacy and teamwork. In doing so, they will become strong, resilient, responsible, professional emerging adults and new solutions and actions will flow from their hands and minds.

It is difficult to chart this precise process of forming a personal moral compass, as has been mentioned above. Participants must become aware of their own set of values, by communicating about these with peers and with the teacher (I call this "the micro level", see van Dijk-Groeneboer 2020). They then have to realize that their set of values might be different from that of others, and they must take a critical look at these values, explore possible alternatives and share experiences by realizing that the actions they take are based on their talents and internalized values (this is "the meso level"). Finally, they also have to relate to society and to the surrounding context (I call this "the macro level"). Together with their family, friends and peer groups, young people learn to discover the benefits of value sets that allow the moral compass to serve a greater good. This entire process must take place without instructing the students on how to build their compass. RE teachers and religious educators have to avoid telling pupils and students how to think and feel, and yet they should encourage them to become aware of and able to communicate about highly abstract matters. Giving the other person space, listening and showing understanding are higher cognitive skills for the students, but they also demand a great deal from the teacher. Teachers have to know their values themselves, also in relation to other people and their values, and have to be able to talk about this. Moreover, they themselves have to be willing to open up to their students, something which makes them vulnerable. It all starts with ensuring that the classroom is a safe space.

The moral compass that people develop will be reshaped continuously throughout their lives, as encounters with others always clarify and further refine people's own values. Furthermore, it allows people to acquire better insights with which they can improve their own set of values. RE classes provide a great opportunity to invite young people to develop this compass and reflect on it, and to teach them tools to keep thinking about this compass throughout their lives. It will make them stronger and happier, and the world as a whole will benefit. Pupils should learn to embark upon a life-long learning process and be encouraged to keep it up to date.

Funding: This research received no external funding.

Conflicts of Interest: The author declares no conflict of interest.

\section{References}

Bakker, Cok, and Nicolina Montesano Montessori, eds. 2016. Complexity in Education: From Horror to Passion. Rotterdam: Sense.

Barbara-i-Molinero, Alba, Rosalía Cascón-Pereira, and Ana beatriz Hernández-Lara. 2017. Professional identity development in higher education: Influencing factors. International Journal of Educational Management 31: 189-203. [CrossRef]

Baumfield, V. 2002. Thinking through Religious Education. Cambridge: Chris Kington.

Bernts, Ton, and Joantine Berghuijs. 2016. God in Nederland 1966-2015. Utrecht: Ten Have. 
Brewer, Margo L., Gisela van Kessel, Brooke Sanderson, Fiona Naumann, Murray Lane, Alan Reubenson, and Alice Carter. 2019. Resilience in Higher Education Students: A Scoping Review. Higher Education Research \& Development 38: 1105-20.

Brooks, David. 2015. The Road to Character. New York: Random House.

Centre for Education Statistics and Evaluation. 2015. Student Wellbeing. Literature Review. Parramatta: NSW Department of Education and Communities.

Collins-Mayo, Sylvia, Bob Mayo, Sally Nash, and Christopher Cocksworth. 2010. The Faith of Generation Y. London: Church House.

Darling-Hammond, Linda. 2006. Powerful Teacher Education: Lessons from Exemplary Programs. New York: Jossey Bass.

De Groot, Isolde. 2013. Adolescents' Democratic Engagement: A Qualitative Study into Dutch Adolescents' Narratives about their Citizenship in a Democratic and Pluralist Society. Enschede: Ipskamp.

Delle Fave, Antonella. 2014. Well-Being in Times of Crisis: Interdisciplinary Evidence and Policy Implications. Journal of Happiness Studies 15: 119-23. [CrossRef]

Dewey, John. 1998. Science and Society. In The Essential Dewey. Pragmatism, Education, Democracy. Edited by L. A. Hickman and T. A. Alexander. Bloomington and Indianapolis: Indiana University Press, vol. 1. First published 1931.

European Values Study. 2020. Available online: www.europeanvaluesstudy.eu (accessed on 12 September 2020).

Geeraerts, Kendra, Päivi Tynjälä, and Hannu Heikkinen. 2018. Inter-generational Learning of Teachers: What and How Do Teachers Learn from Older and Younger Colleagues? European Journal of Teacher Education 41: 479-95. [CrossRef]

Hargreaves, David. 1994. The Mosaic of Learning: Schools and Teachers for the New Century. Demos Paper 8. London: Demos.

Jessen, Daniel C. 2016. Youth: Growing Up. Maitland: Xulon Press.

Joas, Hans, and Klaus Wiegandt. 2008. The Cultural Values of Europe. Translated by Alex Skinner. Liverpool: University Press.

Jongburnout. 2020. Available online: www.jongburnout.nl (accessed on 7 November 2020).

Kienstra, Natascha, Monique van Dijk-Groeneboer, and Olav Boelens. 2018. Religious-Thinking-Through Using Bibliodrama: An Empirical Study of Student Learning in Classroom Teaching. Religious Education 113: 203-16. [CrossRef]

Kools, Quinta, Maaike Koopman, Rian Aarts, and Karin Derksen. Forthcoming. Opleiden en Professionaliseren in Leerateliers. Velon, Tijdschrift voor Lerarenopleiders.

Lanser-van der Velde, Alma M. 2007. Spirituele Vorming in een Agogische Context. In Wat Is Wijs? Reflecties op Spirituele Vorming. Edited by Angela Roothaan and Joke van Saane. Kampen: Ten Have, pp. $27-42$.

Lindner, Konstantin. 2017. Wertebildung im Religionsunterricht: Grundlagen, Herausforderungen und Perspektiven. Paderborn: Schöningh.

Lomos, Catalina. 2012. Professional Community and Student Achievement. Ph.D. dissertation, Rijksuniversiteit Groningen, Groningen, The Netherlands.

Mitchell, J. 2004. Teaching about World Views and Values. Melbourne: Council for Christian Education in Schools.

Nussbaum, Martha Craven. 2010. Not for Profit: Why Democracy Needs the Humanities. Princeton: Princeton University Press.

Pratt, H.D. 2006. Adolescence. In Encyclopedia of Human Development. Edited by Neil J. Salkind. Thousand Oaks: Sage, pp. 29-35.

Roebben, Bert. 2011. Religionspädagogik der Hoffnung. Münster: Lit Verlag.

Schröder, Bernd. 2017. Religionspädagogische Ansatzpunkte und Konsequenzen. In Jugendliche und Religion. Edited by Bernd Schröder, Jan Hermelink and Silke Leonhard. Stuttgart: Kohlhammer, pp. 287-97.

Selçuk, Mualla. 2018. Learning in encounter: Crossroads, Connections, Collaborations. Religious Education 113: 233-44. [CrossRef]

Seymour, Jack Lee, Margaret Ann Crain, and Joseph V. Crockett. 1993. Educating Christians: The Intersection of Meaning, Learning and Vocation. Nashville: Abingdon Press.

Sharkey, Paul. 2019. Religious Education as a Catholic Hermeneutic Space. In Moving from Theory to Practice. Edited by Richard Rymarz and Paul Sharkey. Mulgrave: Vaughan, pp. 123-40.

Shea, John J. 2018. Adulthood, Morality and the Fully Human. Lantham: Lexington Books. 
Stetsenko, A. 2017. Science Education and Transformative Activist Stance. In 13 Questions: Reframing Education's Conversation: Science. Edited by L. A. Bryan and K. Tobin. New York: Peter Lang, pp. 33-47.

The European Commission. 2016. Building Resilience: The EU's Approach. Factsheet. Available online: https://ec.europa.eu/echo/files/aid/countries/factsheets/thematic/EU_building_resilience_en.pdf (accessed on 29 October 2020).

van der Leeuw, K., and P. Mostert. 1991. Filosofie-Opvatting en Onderwijsstijl. VIC Tijdschrift voor Filosofieonderwijs 20: 15-24.

van Dijk-Groeneboer, Monica Catharina Hendrika. 2017. Leren en Leven vanuit je Wortels: Religieuze Educatie voor Iedereen. Inaugural address (In Dutch). Tilburg: Tilburg University.

van Dijk-Groeneboer, Monique. 2020. Who Am I, the Religious Educator? Religion in the Formation of a Moral Compass. Journal of Religious Education 68: 191-200. [CrossRef]

van Dijk-Groeneboer, Monique, and Bernice Brijan. 2013. Kerk uit Zicht? Jongeren Inspireren! Tilburg: Faculteit Katholieke Theologie.

van Dijk-Groeneboer, Monique, and Jacques Maas. 2001. Op Zoektocht: Levenslang! Utrecht: Katholieke Theologische Universiteit.

van Dijk-Groeneboer, Monique, and Jacques Maas. 2005. Geloof? Ff checke! Utrecht: Katholieke Theologische Universiteit.

van Dijk-Groeneboer, Monique, and Briene Van Herpen-de Regt. 2019. Jongeren en hun Waarden. Religie en Samenleving 14: 144-74.

van Dijk-Groeneboer, Monique, Jacques Maas, and Hans Van den Bosch. 2008. Godsdienst? Lekker Belangrijk! Tilburg: Faculteit Katholieke Theologie.

van Dijk-Groeneboer, Monique, Olav Boelens, and Natascha Kienstra. 2017. Geïnspireerde Lessen: Vakspecifieke Werkvormen voor Onderwijs in Godsdienst en Levensbeschouwing. Tilburg: Tilburg University.

White, John. 2004. Should Religious Education Be a Compulsory School Subject? British Journal of Religious Education 26: 152-64. [CrossRef]

Zondag, Hessel, and Marinus van Uden. 2017. Losing My Religion? Religious and Spiritual Coping in Times of Individualisation. Edited by O. van Amelsfoort. Aachen: Shaker Verlag.

Publisher's Note: MDPI stays neutral with regard to jurisdictional claims in published maps and institutional affiliations.

(C) 2020 by the author. Licensee MDPI, Basel, Switzerland. This article is an open access article distributed under the terms and conditions of the Creative Commons Attribution (CC BY) license (http://creativecommons.org/licenses/by/4.0/). 